\title{
Critical Discourse Analysis of the Meme Makasih yang Lebih Cantik
}

\author{
Dita Dewi Palupi, Universitas Airlangga
}

\begin{abstract}
In the study of Critical Discourse Analysis, Fairclough divides discourse into three dimensions, i.e., text, discourse practice, and sociocultural practice. This study aims at investigating the meme Makasih yang Lebih Cantik in Instagram and 1Cak by employing Fairclough's (1989) framework. Furthermore, the study utilizes the theory of compliment response (Herbert, 1989) and politeness strategy (Brown \& Levinson, 1987). By observing the results, it can be concluded that Indonesian women tend to reply the compliment sent to them by saying "Makasih yang lebih cantik" "Thank you, you prettier") since they do not want to be considered to own up the compliment because Indonesian people are not accustomed to hear other people accept compliments by solely saying "Thank you." This becomes the culture in the social structure of Indonesian society that they are the society that upholds politeness, by which is proved by responding compliments with another compliment to be considered as humble.
\end{abstract}

Keywords: compliment response; cyber culture; Fairclough's framework; meme; politeness strategy

\section{Introduction}

The cyberspace becomes the gathering place of people who are interconnected with one another in the internet connection network. Since humans are social beings regardless their origins, they are also able to create a culture in the cyberspace in dabbling in it. The culture in the cyberspace is called as the cyber culture. According to Silver (2008), the cyber culture is comprehended as the culture and its products, such as a set of technology, materials and intellectuals, practices, attitudes, a way of thinking, and values, that are developed along with the development of the cyberspace (Diago, 2012), which exist due to the internet (in Goi, 2009). Thus, everything that is made and conducted in the cyberspace can be categorized into the cyber culture.

In the cyberspace, all people can do everything, whether it is socializing, working, collaborating, communicating, learning, or spreading information (Diago, 2012). Meme, as a form of socialization and communication in the cyberspace becomes extremely popular. The cyberspace renders the best place in reproducing memes. Meme is consumed by the netizens, i.e., the inhabitants of the cyberspace. Meme is widespread and understood as a new culture and considered as a new way to spread information. Meme belongs to the cyber culture (Castells \& Haraway, 2007). The word meme comes from Greek mimema which means 'that which is imitated' (Oxford Living Dictionary, 2017). According to Dawkin (1976) meme is the fundamental unit of culture transmission, or imitation (in Brodie, 2009). It is a culture's gen analogy that is employed to explicate how a rumor, idea, expression, song, or fashion trend can be imitated by a certain population (Bauckhage, 2011). According to Sperber (in Díaz, 2013), meme can also be referred to as the culture replicator. According to Díaz (2013), meme should be considered as a living structure, not only metaphorically but also technically. Meme utilizes communication as one of the methods to reproduce itself (Leigh, 2010). It lives and spreads in the society, mainly since the emergence of social media which renders the rapid distribution of meme. Meme becomes one of the way for a culture to spread in a society, thus they will imitate the culture and distribute it to others.

Meme can show up anywhere, including in the social media such as Instagram and the meme forum site such as 1Cak. One of the well-known meme in Instagram and 1Cak, particularly by Indonesian people, is the meme Makasih yang Lebih Cantik ("Thank you, you prettier"). The meme Makasih yang Lebih Cantik is a meme that attempts to demonstrate in a clearer way the phenomenon of how Indonesian women reply the compliments sent to them. In the meme, it is depicted that a woman who is praised by "You are beautiful" then will reply by saying "Thank 
you, you prettier". This phenomenon is then exploited by Indonesian Instagram users and 1Cak visitors to make as a meme. Indeed, the main reason of the meme creation is solely for fun. Yet, this simple meme also becomes a complex discourse that points out the actual culture of Indonesian women in responding a compliment.

According to Fairclough (1998), if it is seen from the social and historical aspects, language is a form of action in the dialectical relation and social structure, so the analysis regarding language should focus on the formation of language by the social relation and a certain social context. Fairclough (1992) employs discourse to see the language utilization as the social practice instead of human activity to reflect something. He considers that discourse owns three impacts, i.e., discourse contributes to the formation of social identity and subject position; discourse assists the establishment of social relationship among humans; and discourse participates in building the knowledge and belief system (in Eriyanto, 2001). In analyzing discourse, Fairclough (1989) creates a framework which integrates discourse analysis at the levels of text and social condition. In this framework, discourse is not separated away from the social condition in which the discourse appears. Discourse will always be formed in accordance with the social condition around it. Fairclough combines both of them thus the discourse analysis becomes more critical and profound. In Fairclough's framework, the discourse analysis covers three dimensions, i.e., text, discourse practice, and sociocultural practice (Fairclough, 1989).

In the dimension of text, discourse is seen from its language level, how the discourse represents a condition, how the discourse interrelates the writers, readers, and the people who are engaged in the text, and how the discourse presents their identity. Representation can be observed through the utilization of vocabulary and grammar of the text, how the vocabulary is arranged into a sentence and how the sentences are arranged into a discourse. Then, relation is connected with how the writers, readers, and the people engaged in the discourse are interrelated in the text. Then, identity is related to how the identifications of the writers, readers, and the people engaged in the discourse are established in the text (Eriyanto, 2001: 289-305). Moreover, the discourse practice is the dimension that is related to the processes of text production and utilization. According to Fairclough, there are two sides of discourse practice, i.e., the production or text creation by writers or media and the consumption or text utilization by readers or audience. Both are interrelated and even related with other three aspects, i.e., the discourse creation aspect, in which is media or journalist; the relationship of discourse creator and media organization structure; and work practice or routine committed by the discourse creator during the discourse creation process (Eriyanto, 2001: 317). These aspects are interrelated in influencing the final result of produced discourse text. The discourse practice bridges the text and sociocultural practice (Eriyanto, 2001: 321). Afterward, the sociocultural practice is the dimension that assumes that social circumstances outside discourse also contributes in influencing the discourse that emerges in the society. The sociocultural practice indeed does not directly intervene the discourse text production, yet it also contributes in how the discourse text is created and consumed (Eriyanto, 2001: 320). The sociocultural practice renders a certain discourse is able to represent a society's ideology and understanding toward a certain matter as well as to show how the ideology and understanding can be distributed through discourse.

Culture influences how a compliment and compliment response is expressed. A compliment is a speech act which expresses award implicitly or explicitly to a person for the good things that are considered positive by both the speaker and the hearer (Holmes in Milinkovic, 2010). The compliment and its function differ from one culture and another (Herbert, 1989). Meanwhile, a compliment response is an answer, expression, or reaction toward a speaker's opinion to a hearer (Turangan \& Gunawan, 2013). The compliment response even demonstrates the more various variability compared to the compliment itself (Herbert, 1989: 6). Herbert (1989) divides the types of compliment response into two big divisions, i.e., agreement and non- agreement. Agreement is the compliment response in the form of acceptance of the compliment. Agreement consists of appreciation token, comment acceptance, praise upgrade, comment history, reassignment, and return. Meanwhile, non-agreement is the compliment response in the 
form of rejection, transference, or question. Non-agreement comprises scale down, disagreement, qualification, question, no acknowledgement, and request interpretation.

Sometimes, a person's way in responding compliment depicts that the person attempts to demonstrate a politeness strategy in it. According to Weydt (1983), politeness is a pragmatic mechanism which structural diversity (including the non-verbal and prosody features) cooperates in accordance with the speaker's intention to reach the smooth communication (in Rahayu, 2009). Politeness, like the compliment response, differs in various cultures (Holmes, 1988 in Sukarno, 2015). According to Goffman (1956), what is actually meant to be saved by politeness strategy is the face (in Renkema, 2004). In the politeness context, face is the self-image that a person intentionally shows to public (Al-Azzawi, 2011). With the face concept, Brown and Levinson (1987) develop the theory that relates the threat level toward a person's face and the politeness regarding language. They state that there are two components of face, i.e., positive face, which demonstrates all people's desire to be liked by other people and it tends to depict informal politeness, and negative face, which demonstrates the desire of 'competent adult' to be unblocked by others and it tends to show formal politeness (Brown \& Levinson, 1987).

There are several studies that employ Fairclough's framework in investigating the social cases. Adrianto (2012) exploited Fairclough's framework in analyzing the report of the formation of the leadership reputation of Susilo Bambang Yudhoyono in Pikiran Rakyat and Kompas daily newspapers. He discovered that in Pikiran Rakyat daily newspaper, the produced text tended to provide negative reputation while the produced text in Kompas daily newspaper tended to depict positive reputation. In another study, Prihantoro and Fitriani (2015) also employed Fairclough's framework to investigate the modality in online news texts by using corpus. The obtained result was that there were several modality types in the collected data, i.e., intentional, epistemic, deontic, dynamic, and alethic. Meanwhile, Albaburrahim (2017) utilized Fairclough's framework in discussing the discourse in the report of Papa Minta Saham case in Metro TV. He found that the news text employed by Metro TV tended to be in the form of argumentation and description, the employed discourse tended discuss the violation issue committed by the former chairman of People's Representative Council, and Metro TV tended to report on the negative things related to the former chairman. By seeing the previous studies, it can be seen that there has yet been any study on meme employing Fairclough's framework. The purpose of this study is investigating the meme Makasih yang Lebih Cantik in Instagram and 1Cak. The meme is analyzed by employing Fairclough's (2001) framework and observed further by utilizing the theories of compliment response (Herbert, 1989) and politeness strategy (Brown \& Levinson, 1987). This study also attempts to see how the meme actually represents Indonesian women's culture in accepting and responding to compliments, and the sentence makasih yang lebih cantik becomes the common answer in social media like Instagram and $1 \mathrm{Cak}$.

\section{Method of the study}

This study employs descriptive qualitative approach. The object of the study is the meme Makasih yang Lebih Cantik. This meme is investigated using Fairclough's (1989) framework, i.e., by observing the linguistic aspect, that is the sentence makasih yang lebih cantik, and the nonlinguistic aspects, that is the discourse practice that renders the emergence and spread of the meme by inspecting what happens in the formation process of the meme and the sociocultural practice which investigates the cultural phenomenon related to the meme Makasih yang Lebih Cantik by utilizing the theory of compliment response (Herbert, 1989) and politeness strategy (Brown \& Levinson, 1987).

\section{Results and discussion}

In this study, the analysis is divided into three dimensions, i.e., at the levels of text, discourse practice, and sociocultural practice. In the analysis of text, what becomes the discussion focus is the conversation in the text along with the sentence makasih yang lebih cantik as the main focus. 
Figure 1: Meme in Instagram

(source: instagram.com/ukik.rm)

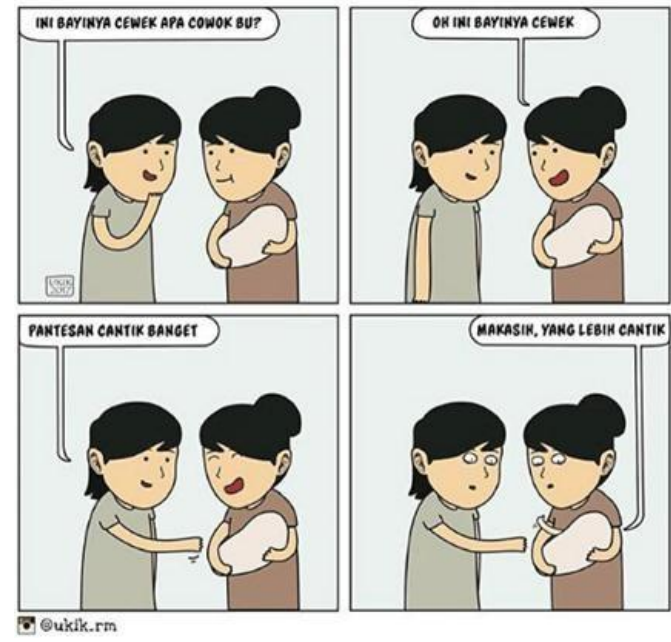

Figure 2: Meme in 1Cak (source: 1cak.com/1091919)

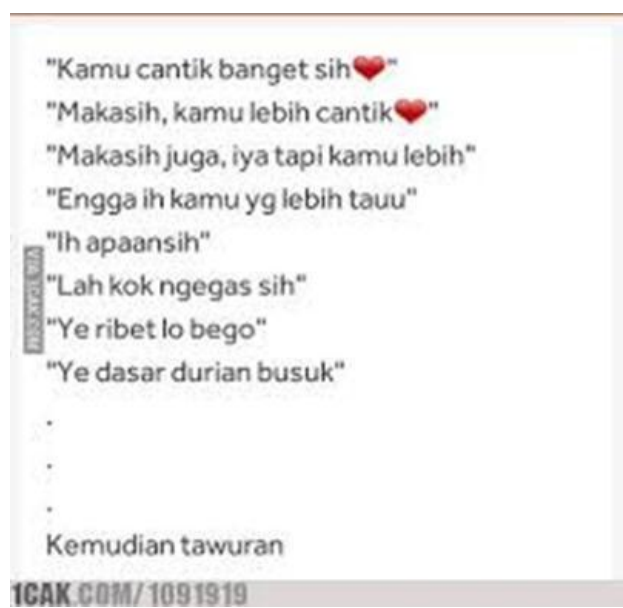

In Figure 1, it can be seen that the meme attempts to depict that women, either they are still infant, will directly respond the compliment "Beautiful" with "Thank you, you prettier". This becomes the common compliment response that will automatically be said by all women when they are praised as "Beautiful". Then in Figure 2, it can be observed that when a woman is praised as "Beautiful" and being replied by "Thank you, you prettier", then the process of replying the compliments will never end. Instead, both women will keep praising until they fight since they become exhausted in throwing the endless compliments to each other. The sentence "Ih apaan sih" ("Ew what the hell") is considered as a harsh answer, thus the next answer is "Lah kok ngegas" ("Hey why are you mad") which indicates that the hearer asks why the speaker becomes furious due to being praised back. The answer "Ye ribet lo bego" ("You are so complicated, moron") indicates that the speaker is fed up of being praised back by the hearer instead of merely replying with "Thank you" for the compliment sent to her.

The sentence "Makasih yang lebih cantik" ("Thank you, you prettier") is a compliment response. This sentence is more likely to be addressed to women since there is the word cantik (beautiful) in it, and the word cantik has many collocations with the word wanita (women) and gadis (girl) (SEAlang Library, 2017). This sentence indicates that the hearer attempts to receive the compliment, yet she does not want to own up the compliment. Thus, after mentioning "thank 
you," the sentence "you prettier" is added up to show that the speaker is also beautiful or even more than the hearer. If it is seen from the theory of compliment response (Herbert, 1989), the sentence "Makasih yang lebih cantik" is a compliment response that belongs to the category of agreement. The word makasih (thank you) is the compliment response in the form of appreciation token, which is the form of compliment response by replying the compliment with appreciating sentences or gestures, such as "thank you" and nodding. Meanwhile, the sentence yang lebih cantik (you prettier) is the compliment response in the form of return, that is giving back the compliment to the speaker, such as "you, too" (in Tiono \& Nova, 2007). This demonstrates that Indonesian women tend to do return in responding compliments (Diana, 2012). This indicates that women tend to be humble in responding compliments (Tannen in Diana, 2012).

Then, in the analysis of discourse practice, social media like Instagram and meme forum site like 1Cak also contribute in the creation and distribution of the meme Makasih yang Lebih Cantik. The content contribution for these platforms not only comes from the owners of the platforms, but it also comes from Indonesian society who are also engaged in providing the content suggestion in the platforms. The society might upload the meme to the platform to share the new phenomenon. The content contributors, i.e., Indonesian society who use the platforms, indeed encounter the phenomenon of responding compliment by saying "Thank you, you prettier" in the platforms, which mostly occurs in Instagram's comment section. It usually happens when there is a beautiful woman being praised by "You are so beautiful," then the woman will reply by saying "Thank you, you prettier." By seeing this phenomenon, the content contributors attempt to inform the audience of these platforms that this phenomenon actually exists and develops in the social media, which renders the emergence of this meme. Then the meme is being distributed to other users in the platforms so that they will know the existence of the phenomenon.

In the analysis of sociocultural practice, it can be observed that in the culture of Indonesian society, accepting compliments by solely saying "thank you" becomes an uncommon thing. Indonesian society is the collective society which prioritizes shared or group perception instead of individual perception. Indonesian society, particularly Indonesian women, tend to hesitate in owning up the compliments sent to them, and "thank you" is the uncommon answer in responding compliments. This happens since they are afraid of being considered as arrogant by other people who hear their response toward the compliments (Oktaviani, 2015). Solely saying "thank you" will give the person saying it the bad impression since Indonesian culture considers humbleness as the good attitude (Kuntjara, 2003) and merely answering with "thank you" is contradictory to the politeness norm in Indonesian culture. Therefore, Indonesian women feel demanded to not responding compliment only by saying "thank you", yet they tend to reply with additional sentences, such as praising back the speaker who praises them, or tend to refuse the compliment.

\section{Conclusion}

By employing Fairclough's (1989) framework, it can be seen that Indonesian women are more likely to praise back the people who praise them by saying "Makasih yang lebih cantik" ("Thank you, you prettier") since they do not want to be considered as owning up the compliment. It happens since Indonesian people are uncommon in hearing other people accepting compliment by solely saying "thank you". This becomes the culture in the social structure of Indonesian society who considers that humbleness is the good and appropriate attitude and responding compliments by praising back will be considered as more polite instead of merely saying "thank you." By the existence of this phenomenon, thus the Instagram and 1Cak users exploit this by creating the meme Makasih yang Lebih Cantik to inform Indonesian netizen that this phenomenon actually exists and develops in the cyberspace.

\section{References}

Albaburrahim, A. 2017. Analisis wacana kritis pada pemberitaan kasus papa minta saham di Metro TV. Lingua Franca: Jurnal Bahasa, Sastra, dan Pengajarannya, 1(2), 1-12. 
Ardianto, E. 2012. Analisis wacana kritis pemberitaan harian pikiran rakyat dan harian Kompas sebagai public relations politik dalam membentuk branding reputation Presiden Susilo Bambang Yudhoyono (SBY). Jurnal Ilmu Komunikasi, 2(1), 14-57.

Al-Azzawi, J. N. 2011. Compliments and positive politeness strategies. Journal of the College of Basic Education, 17(71), 111-126.

Brodie, R. 2009. Virus of the mind. Carlsbad: Hay House.

Brown, P. \& Levinson, S. C. 1987. Politeness: Some universals in language usage (studies in interactional sociolinguistics). Cambridge: Cambridge University Press.

Castells, M., \& Haraway, D. 2007. Why cyberculture? In D. Bell (ed.). Cyberculture Theorists. New York: Routledge.

Diago, G.G. 2012. Cyberspace and cyberculture. In M. Kosut, \& G. J. Geoffrey (eds.). Encyclopedia of Gender in Media. SAGE reference publication.

Díaz, C. M. C. 2013. Defining and characterizing the concept of internet meme. CES Psicología, 6(1), 82-104.

Eriyanto. 2001. Analisis wacana: Pengantar analisis teks media. Yogyakarta: LKiS.

Fairclough, N. 1989. Language and power (2nd ed.). London: Routledge.

Goi, C. L. 2009. Cyberculture: Impacts on netizen. Asian Culture and History, 1(2), 140-143).

Herbert, R. K. 1989. The ethnography of English compliment and compliment responses: A contrastive sketch. In W. Oleksy (ed.). Contrastive Pragmatics. Amsterdam: John Benjamins Publishing Company, 3-36.

Indonesian Text Corpus. Available at http://sealang.net/indonesia/corpus.htm. (Accessed 16 June 2018).

Kuntjara, E. 2003. Gender, bahasa, dan kekuasaan. Jakarta: BPK Gunung Mulia.

Leigh, H. 2010. Genes, memes, culture, and mental illness: Toward an integrative model. Springer Science \& Business Media.

Milinkovic, T. 2010. Compliments on possessions in Australian English. Griffith Working Papers in Pragmatics and Intercultural Communication, 3(2), 83-94.

Oxford English Living Dictionary Daring. Available at https://en.oxforddictionaries.com/definition/meme. (Accessed 16 June 2018).

Penyebab Wanita Indonesia Takut Mengakui Dirinya Cantik. Available at https://wolipop.detik.com/read/2015/04/17/060258/2889907/234/penyebab- wanitaindonesia-takut-mengakui-dirinya-cantik. (Accessed 16 June 2018).

Prihantoro, E, \& Fitriani, D. R. 2015. Modalitas dalam teks berita media online. Prosiding PESAT. Depok: Universitas Gunadarma, 17-25.

Rahayu, I. R. 2009. Politeness strategies in giving and responding to compliments: A sociopragmatics study of compliments in "the devil wears prada". Bachelor thesis. Universitas Sebelas Maret, Surakarta, Indonesia.

Renkema, J. 2004. Introduction to discourse studies. Amsterdam: John Benjamins Publishing Co.

Sukarno. 2015. Politeness strategies in responding to compliments in Javanese. Indonesian Journal of Applied Linguistics, 4(2), 91-101.

Tiono, N. I., \& Nova, I. 2007. The compliments and the compliment responses used by the characters in What Women Want. K@ ta Lama, 9(1), 78-90.

Turangan, Y. M., \& Gunawan, S. 2013. The compliment responses used by Herbalife's male and female customers in Surabaya. K@ ta Kita, 1(1), 212-216. 